\title{
PENYULUHAN BAGI IBU-IBU PENGGERAK EKONOMI PRODUKTIF RINTISAN DI KECAMATAN DAHA UTARA
}

\author{
Titien Agustina ${ }^{1}$, Sulaiman $^{2}$, Muhammad Rudiansyah $^{3}$, Nurhikmah $^{4}$, Maulana $^{5}$, Alfiannor $^{6}$, \\ M. Rio Mursyid Wijaya ${ }^{7}$, Chumaidi $^{8}$ \\ $1,2,3,4,5,6,7,8$ STIMI Banjarmasin \\ Email: titienagustina9@gmail.com
}

\begin{abstract}
ABSTRAK
Pembangunan sumber daya manusia pada sektor industry rumahan yang kebanyakan dilakukan oleh SDM dengan sumber daya yang terbatas namun memiliki kemauan untuk bisa menghasilkan dan memberi dampak pada sumber ekonomi keluarga maupun masyarakat. Ibu-ibu yang menjadi penggerak ekonomi produktif rintisan ini umumnya masih lemah dalam kapasitas dan kapabilitasnya di dalam mengembangkan usaha, baik dalam segi manajemen usaha secara umum, manajemen keuangan, manajemen produksi, manajemen pemasaran, hingga manajemen SDM dirinya sendiri agar tergali potensi terdalam yang dimiliki. Melalui kegiatan penyuluhan menjadi salah satu upaya untuk membantu memberi pencerahan, penambahan ilmu dan wawasan serta keterampilan, sehingga tumbuh kecerdasan dalam melakukan sesuatu dan menghasilkan apa yang diinginkan, bahkan melahirkan kreativitas dan inovasi pada tahap berikutnya.
\end{abstract}

Kata kunci: ibu-ibu rumah tangga, industri rumahan, industrI olahan, stakeholder

\section{EDUCATION FOR PRODUCTION ACTIVE MOTHER MOTIVES IN DAHA UTARA}

\begin{abstract}
Human resource development in the home industry sector is mostly done by human resources with limited resources but have the will to be able to produce and have an impact on family and community economic resources. Mothers who are pioneers of productive economy in this pioneering are generally still weak in their capacity and capability in developing business, both in terms of business management in general, financial management, production management, marketing management, to human resource management itself in order to explore the deepest potential possessed. Through counseling activities become one of the efforts to help enlighten, add knowledge and insight and skills, so that intelligence grows in doing something and produces what is desired, even giving birth to creativity and innovation at a later stage.
\end{abstract}

Keywords: housewives, home industry, processed industry, stakeholders

\section{PENDAHULUAN}

Perguruan Tinggi memiliki tugas dalam melaksanakan tridharma yang terdiri dari pendidikan dan pengajaran, penelitian, dan pengabdian kepada masyarakat. Perguruan tinggi yang terdiri dari tenaga pendidik atau disebut dosen, juga tenaga kependidikan dan mahasiswa serta stakeholder lainnya adalah bagian dari sivitas akademika sebuah perguruan tinggi. Masing-masing memiliki tugas dan tanggung jawab yang tidak terpisahkan dalam kedudukannya masing-masing.

Dosen dituntut selain mengajar di kelas, juga memiliki kewajiban untuk turun ke masyarakat dalam rangka mengejawantahkan ilmu dan teori yang didapat maupun dikembangkannya di kampus. Kegiatan dosen turun ke masyarakat, bisa dalam bentuk penelitian. Tetapi bisa juga dalam bentuk kegiatan pengabdian kepada masyarakat sebagai pengejawantahan ilmu, teori dan pengalamannya di kampus, dalam penelitian, maupun upaya untuk membangun sinergisitas antara perguruan tinggi, dosen dan 
BAKTI BANUA : Jurnal Pengabdian Kepada Masyarakat

Volume 1 No. 1 Mei 2020

https://ejurnal.stimi-bjm.ac.id/index.php/BBJM/

masyarakat. Sehingga terbangun suatu hubungan yang lurus, dimana ilmu yang sudah dikembangkan di kampus, harus dijewantahkan lagi pada masyarakat. Bukan saja sebagai alat penguji atau ujicoba, maupun praktek lapangan, tetapi juga guna membantu masyarakat dalam mencari solusi persoalan yang dihadapi.

Dosen dalam kegiatan pengabdian masyarakat, dituntut juga melibatkan mahasiswa agar bisa menjadi contoh, serta menjadi pengalaman bagi mahasiswa dalam melakukan kegiatan bersama masyarakat. Baik terkait penyebaran ilmu melalui pencerahan, penelusuran permasalahan yang ada di masyarakat, baik yang berpotensi maupun belum timbul kepermukaan. Sehingga mahasiswa sebagai penerus generasi masa depan akan mendapatkan pencerahan, pengalaman, dan sekaligus ilmu. Ilmu yang sangat komprehensif. Karena begitu duduk bersama masyarakat, akan banyak persoalan yang dilemparkan dan muncul kepermukaan. Seorang dosen yang merupakan ilmuwan, mestinya bisa mencarikan dan memberikan langkah-langkah solusi kepada masyarakat atas persoalan tersebut. Dari sinilah mahasiswa akan mendapatkan pengalaman, wawasan dan bisa memetik softskills dalam mengelola pemikiranpemikiran yang berbeda. Penyatuan pendapat yang berbeda, maupun teknik dalam mencarikan solusi yang terbaik bagi persoalan yang muncul di masyarakat hingga bentuk penyelesaian yang terbaik.

Melalui kegiatan penyuluhan sekaligus memberi dorongan dalam bentuk pembimbingan dan pendampingan kepada ibu-ibu rumah tangga di Kecamatan Daha Utara, Kabupaten Hulu Sungai Selatan, sekitar 130 kilomater dari ibukota Provinsi Kalimantan Selatan, Banjarmasin. Daha Utara dahulu dikenal dengan nama Negara, berada di pinggiran Sungai Amandit. Sejak dahulu sudah dikenal sebagai masyarakat pedagang yang daerah ini dilewati oleh pedagang-pedagang dari Kelua, Amuntai, dan lainnya yang membawa dagangan hasil produksi sendiri maupun orang-orang yang ada di desanya untuk dibawa dan dijual ke desa-desa lainnya hingga sampai ke Banjarmasin dengan menggunakan alat tranportasi sungai. Perjalanan berdagang seperti ini bisa menempuh waktu berbulan-bulan hingga di perahu atau kapal yang digunakan juga diikuti oleh beberapa keluarga dan anggota keluarganya.

Banyak hasil bumi dan juga hasil produksi dari daerah sekitar yang diperdagangkan dengan cara ini. Termasuk juga hasil produksi rumahan yang diproduksi oleh ibu-ibu rumah tangga melalui hasil olahan seadanya yang berasal dari sumber daya lingkungan desa dan sekitarnya. Dengan kondisi sungai dan daerah rawa, banyak hasil bumi dari dalam sungai seperti berbagai jenis ikan sungai, hasil tanaman dari lahan pertanian dan rawa yang menghasilkan. Umumnya adalah buah dan sayuran lokal seperti buah labu atau waluh kuning, juga waluh putih, mentimun, lambok, kacang, terong, tomat, karawila, ubi kayu dan ubi lancar, semangka, serta beras dan lainnya.

Hasil pertanian serta sumber daya alam yang ada disekitar inilah yang menjadi sumber kehidupan masyarakat desa ini dan sekitarnya sejak dahulu yang bisa menghidupi keluarga dan masyarakatnya. Dengan kemajuan peradaban masyarakatnya, serta ditopang dengan makin mudah dan lancarnya transportasi darat, menjadikan hasil-hasil pertanian dan olahan rumahan ini bisa langsung dibawa ke berbagai kota dan tempat. Namun sayang, hasil olahan rumahan yang dilakukan ibu-ibu rumah tangga ini masih tertinggal. Karena umumnya mereka menjual langsung hasil sumber daya alam tanpa mengolah lebih lanjut. Begitu alam sedang bermasalah, maka banyak keluarga yang kehilangan sumber kehidupan dan penghidupannya. Sehingga secara ekonomi bisa menjadi timpang dan menurun drastis.

Melalui kegiatan penyuluhan dan pemberdayaan masyarakat ini, tim memberikan motivasi, penyuluhan dan pembimbingan dalan mengolah hasil alam dan sekitarnya untuk bisa memiliki atau menambah nilai ekonomi, bersaing, dan bahkan mampu merambah kebutuhan di pasar modern. Selain itu dengan perbaikan kualitas produksi dan kualitas pemasaran maka diharapkan juga hasil produksi ibu-ibu bisa dipasarkan pula dengan jangkauan yang lebih luas serta daring melalui pemasaran online di market place. Sehingga ekonomi keluarga akan meningkat yang pada akhirnya juga berdampak pada peningkatan ekonomi masyarakat sekitar.

\section{KAJIAN TEORITIS}

Usaha mikro sebagai bagian dari Usaha Mikro, Kecil dan Menengah (UMKM) yang umumnya digerakkan oleh anggota masyarakat dengan mengerahkan segala kemampuan yang 
BAKTI BANUA : Jurnal Pengabdian Kepada Masyarakat

Volume 1 No. 1 Mei 2020

https://ejurnal.stimi-bjm.ac.id/index.php/BBJM/

seadanya (Agustina, 2019) dilingkungannya, adalah suatu hal yang nyata. Kehadirannya di setiap lingkungan masyarakat, akan memberi dampak yang tidak kecil. Bahkan dampak itu dirasakan sangat besar ketika kondisi masyarakat dan negara menghadapi krisis ekonomi, kehadiran UMKM mampu menjadi penyelamat perekonomian negara (Tambunan, 2012); (Suryana, 2013); (Agustina, Titien; Candrarin, G.; Manan, 2017).

Pada kenyataannya, kehadiran UMKM dalam kegiatan perekonomian yang ada di suatu wilayah atau masyarakat, tidak diragukan. Dari ratusan juta penggerak UMKM, ada sekitar 98\% nya adalah yang berskala mikro. Salah satu pelaku dan penggerak UMKM adalah kaum perempuan atau ibu-ibu rumah tangga yang awalnya hanya menyandang status ibu rumah tangga. Namun dengan perkembangan masyarakat dan kebutuhan ekonomi keluarga dan masyarakat, menyebabkan perempuan atau ibu-ibu yang sebelumnya hanya tinggal dirumah, mengurus rumah tangga, mengurus keluarga dan membesarkan anak-anak, mulai bergerak menjadi pelaku usaha yang mulai melirik kegiatan ekonomi produktif (Dipta, 2009). Banyak perempuan atau ibu-ibu yang semua hanya bekerja di sektor pertanian yang kemudian berpindah ke sektor industry (Panggabean, Hasugian, 2019) khususnya industri rumahan yang tidak jauh dari kegiatan pokoknya di rumah.

Seiring dengan berkembangnya tuntutan kehidupan dan makin tingginya kebutuhan keluarga, maka peran perempuan atau ibu-ibu pada sektor industri ini tidak bisa dipandang sebelah mata. Dari sekian banyak jumlah pengusaha UMKM, maka perempuan menempati jumlah yang tidak sedikit serta memberikan peranannya yang sangat besar dalam sektor industri makanan, perdagangan, dan jasa lainnya (Dipta, 2009); (Panggabean, Hasugian, 2019); (Priminingtyas, 2010).

Oleh karena itu penting upaya meningkatkan sumber daya manusia kalangan ibu-ibu rumah tangga yang sudah merambah sektor publik dan menjadi penggerak ekonomi produktif yang bisa memenuhi kebutuhan sektor industri, walaupun masih dalam tahap industri mikro dan kecil. Namun peran perempuan atau ibu-ibu ini tidak bisa dipandang sebelah mata. Karena kontribusi yang sudah diberikannya pada pendapatan daerah dalam beberapa sektor menunjukkan angka yang terus meningkat. Misalnya saja pada sektor industri pengolahan tembakau yang ada di Kota Malang, dari jumlah tenaga kerja yang ada sebesar 33.262 yang ada disektor industry, maka ada 26.151 orang tenaga kerja di sektor industri pengolahan dimana 80\% dari jumlah itu adalah tenaga kerja perempuan (Priminingtyas, 2010). Sehingga peran perempuan tidak bisa diabaikan dan untuk itu harus mendapat perhatian dari segala pihak. Karena pasti akan memberikan dampak untuk ekonomi keluarga, masyarakat, dan negara. Termasuk pada industri rumahan yang dilakoni oleh ibu-ibu yang ada di Daha Utara Kabupaten Hulu Sungai Selatan, khususnya pada kaum perempuannya banyak bergerak di industri olahan rumahan.

\section{METODE}

Metode penyuluhan pertanian erat kaitannya dengan metode belajar orang dewasa (andragogy). Penyuluh, yang menjalankan tugas utamanya sebagai pendidik, pengajar dan pendorong, selalu berhubungan dengan sasaran penyuluhan yang biasanya adalah para petani, peternak, dan nelayan dewasa. Menurut Mardikanto (1993), sebagai suatu proses pendidikan, maka keberhasilan penyuluhan sangat dipengaruhi oleh proses belajar yang dialami dan dilakukan oleh sasaran penyuluhan. Dalam pelaksanaan penyuluhan, pemahaman proses belajar pada orang dewasa serta prinsip-prinsip yang harus dipegang oleh seorang penyuluh dalam 
BAKTI BANUA : Jurnal Pengabdian Kepada Masyarakat

Volume 1 No. 1 Mei 2020

https://ejurnal.stimi-bjm.ac.id/index.php/BBJM/

menjalankan tugasnya menjadi sangat penting peranannya karena dapat membantu penyuluh dalam mencapai tujuan penyuluhan yang telah ditentukannya.

Menurut Van den Ban dan Hawkins (1999) dalam Kusumawardani (2013), pilihan seorang agen penyuluhan terhadap satu metode atau teknik penyuluhan sangat tergantung kepada tujuan khusus yang ingin dicapainya dan situasi kerjanya. Karena beragamnya metode penyuluhan yang dapat digunakan dalam kegiatan penyuluhan, maka perlu diketahui penggolongan metode penyuluhan menurut jumlah sasaran yang hendak dicapai. Berdasarkan pendekatan sasaran yang ingin dicapai, penggolongan metode terbagi menjadi tiga yakni metode berdasarkan pendekatan perorangan, kelompok, dan massal.

Dalam kesempatan ini maka yang akan dibahas hanya yang terkait dengan metode penyuluhan yang digunakan, yaitu pendekatan perorangan. Pada proses transfer ilmu pengetahuan mau pun informasi maka penggunaan panca indera tidak terlepas dari suatu proses belajar mengajar seseorang karena panca indera tersebut selalu terlibat di dalamnya. Hal ini dinyatakan oleh Socony Vacum Oil Co dalam penelitiannya memperoleh hasil sebagai berikut: $1 \%$ melalui indera pengecap, $1,5 \%$ melalui indera peraba, 3\% melalui indera pencium, $11 \%$ melalui indera pendengar dan 83\% melalui indera penglihat (Kusumawardani, 2013). Pada proses transfer ilmu maupun informasi dalam metode perorangan, maka peranan indera sangat dominan.

Dalam mempelajari sesuatu, seseorang akan mengalami suatu proses untuk mengambil suatu keputusan yang berlangsung secara bertahap melalui serangkaian pengalaman mental psikologis sebagai berikut:

1) Tahap sadar, yaitu sasaran mulai sadar tentang adanya inovasi yang ditawarkan oleh penyuluh

2) Tahap minat, yaitu tumbuhnya minat yang seringkali ditandai oleh keinginan untuk bertanya atau untuk mengetahui lebih banyak tentang segala sesuatu yang berkaitan dengan inovasi yang ditawarkan oleh penyuluh.

3) Tahap menilai yaitu penilaian terhadap baik/buruk atau manfaat inovasi yang telah diketahui informasinya secara lebih lengkap.

4) Tahap mencoba yaitu tahap dimana sasaran mulai mencoba dalam skala kecil untuk lebih meyakinkan penilaiannya, sebelum menerapkan untuk skala yang lebih luas.

5) Tahap menerapkan yaitu sasaran dengan penuh keyakinan berdasarkan penilaian dan uji coba yang telah dilakukan/diamati sendiri.

Jadi tujuan pemilihan metode penyuluhan adalah:

1) Agar penyuluh dapat menetapkan suatu metode atau kombinasi beberapa metode yang tepat dan berhasil guna,

2) Agar kegiatan penyuluhan yang dilaksanakan untuk menimbulkan perubahan yang dikehendaki yaitu perubahan perilaku pada yang bersangkutan dan anggota keluarganya dapat berdayaguna dan berhasil guna.

Dalam metode ini, penyuluh berhubungan secara langsung maupun tidak langsung dengan sasarannya secara perorangan. Metode perorangan atau personal approach menurut Kartasaputra dalam (Kusumawardani, 2013), sangat efektif digunakan dalam penyuluhan karena sasaran dapat secara langsung memecahkan masalahnya dengan bimbingan khusus dari penyuluh. Adapun jika dilihat dari segi jumlah sasaran yang ingin dicapai, metode ini kurang efektif karena terbatasnya jangkauan penyuluh untuk mengunjungi dan membimbing sasaran secara individu. Metode pendekatan individu akan lebih tepat digunakan dalam mendekati tokoh-tokoh masyarakat yang berpengaruh ataupun pada golongan petani atau peternak yang menjadi panutan masyarakat setempat. 
BAKTI BANUA : Jurnal Pengabdian Kepada Masyarakat

Volume 1 No. 1 Mei 2020

https://ejurnal.stimi-bjm.ac.id/index.php/BBJM/

Menurut Van den Ban dan Hawkins (1999) dalam Kusumawardani (2013), metode pendekatan perorangan pada hakikatnya adalah paling efektif dan intensif dibanding metode lainnya, namun karena berbagai kelemahan di dalamnya, maka pendekatan ini jarang diterapkan pada program-program penyuluhan yang membutuhkan waktu yang relatif cepat. Dalam hal ini para penyuluh berhubungan secara langsung maupun tidak langsung dengan sasaran secara perorangan. Contohnya:

a. Kunjungan ke rumah petani, ataupun petani berkunjung ke rumah penyuluh dan ke kantor.

b. Surat menyurat secara perorangan.

c. Demonstrasi pilot.

d. Belajar perorangan, belajar praktek.

e. Hubungan telepon

Kegiatan pengabdian masyarakat ini dilaksanakan dengan metode penyuluhan yang dilakukan dengan cara pendekatan personal atau perorangan. Awalnya dikumpulkan untuk diberikan pengarahan dan motivasi. Selanjutnya dilakukan pendekatan secara personal agar lebih memadai dan mendekati pada persoalan yang dihadapi masing-masing pelaku usaha. Karena pada masyarakat desa dengan karakteristik personal yang berbeda dan lebih banyak menghadapi keterbatasan dalam pendidikan, pengetahuan, keterampilan, komunikasi, permodalan, dan kemampuan personal, sehingga diperlukan Teknik pendekatan yang langsung bersentuhan dengan personal yang bersangkutan. Karena setiap ibu rumah tangga yang melakukan kegiatan ekonomi produktif rintisan seperti ini berbeda dalam kemampuan daya serap dan daya tangkap, sehingga sangat diperlukan pendekatan personal atau perorangan agar tujuan penyuluhan dan pendampingan bisa tercapai.

\section{HASIL DAN PEMBAHASAN}

Keterbatasan pengetahuan dan ilmu yang dimiliki oleh ibu-ibu yang menjalankan usaha rumahan maupun usaha kecil sebagai kegiatan ekonomi produktif rumahan, membuat usaha yang dijalankan cenderung berjalan ditempat bahkan sulit berkembang. Ketika hendak melakukan pengembangan usaha dan melakukan pinjaman kepada perbankan, kendala utama yang dihadapi adalah manajemen keuangan usaha (Widayat, 2018) serta administrasi organisasi usaha yang tidak ada sehingga sulit bagi perbankan mencairkan pinjaman. Melalui kegiatan penyuluhan dan pemberdayaan ekonomi produktif yang dilakukan dengan pembekalan kepada ibu-ibu rumah tangga agar memiliki pengetahuan dan keterampulan bagaimana mengelola usaha dengan baik termasuk manajemen produksi agar marketable, tentu dibutuhkan pelatihan dan penyuluhan, sehingga berubah pola pikir, pola sikap dan perilaku nyata di dalam menjalankan usaha.

Tidak mudah memang menumbuhkan jiwa kewirausahaan, apalagi pada masyarakat yang secara formal jauh dari pendidikan dan pengalaman yang baik. Oleh karena itu diperlukan upaya yang sabar dan berkelanjutan dalam membantu pemerintah guna membangun pola pikir dan pola sikap yang sesuai dengan tuntutan pasar dan konsumen yang makin cerdas. Pada masyarakat yang sudah melek informasi melalui berbagai teknologi, maka pengetahuan dan kesadaran berkonsumsinya sudah mulai tumbuh dan baik, sehingga di dalam memilih suatu produk pasti akan memperhatikan berbagai syarat kebersihan, kesehatan, dan juga bahkan keindahan dan rasa/selera.

Umumnya ibu-ibu di desa dengan segala keterbatasan yang dimiliki, mampu berproduksi sudah sangat baik, sehingga bisa menunjang ekonomi keluarga. Namun dalam kondisi peradaban modern sekarang ini, dengan tuntutan konsumen yang makin serdas serta persaingan yang makin 
BAKTI BANUA : Jurnal Pengabdian Kepada Masyarakat

Volume 1 No. 1 Mei 2020

https:/ / ejurnal.stimi-bjm.ac.id/index.php/BBJM/

ketat, tentu sebagai produsen, diperlukan upaya-upaya untuk merubah pola pikir dan sikap perilaku yang sesuai dengan tuntutan sasaran pasar dimana produk akhir akan dilempar. Banyak pelaku usaha ekonomi produktif rintisan ini yang sangat mengabaikan perbaikan kualitas produk dan kualitas layanan. Padahal di tengah kompetisi yang ketat, bila tidak memperhatikan hal tersebut, tentu ada banyak pilihan produk dan banyak pilihan berbelanja yang bisa dilakukan konsumen.

Ibu-ibu rumah tangga yang mulai kesadaran berekonomi produktif ini harus disambut dengan baik oleh berbagai pihak. Selanjutnya diarahkan dan harus dibimbing agar mampu memenuhi pasar konsumen yang sesuai dengan tuntutan yang ada. Ada beberapa hal penting yang harus diperhatikan dalam melakukan perubahan kesadaran berproduksi yang dilakukan oleh ibu-ibu rumah tangga ini, agar terbangun kemampuan manajemen usaha yang baik, yaitu:

1. Tahap berproduksi harus mampu dilakukan dengan tetap mengedepankan kualitas produk olahan yang dihasilkan. Tentunya kualitas olahan seperti kue kering khas Negara, ikan sepat kering, kacang putih, kacang goreng, kripik ubi kayu, krupuk berbahan dasar ikan, dll, haruslah tetap memperhatikan segi-segi kesehatan, kebersihan, keamanan. Baik selama proses pemilihan bahan baku, proses pengolahan, hingga menghasilkan produk olahan jadi. Karena banyak industry rumahan yang kurang memperhatikan segi kebersihan dan kesehatan serta keamanan. Khususnya kesehatan dan keamanan dalam penggunaan bahan campuran, misalnya penggunaan zat pewarna, bahan baku campuran, dll. Hanya karena ketidak-tahuan akan hal-hal tersebut yang disebabkan oleh minimnya pengetahuan maupun informasi yang dimiliki tentang hal tersebut. Oleh karena itu, ibu-ibu ekonomi produktif ini harus dibina lagi oleh stakeholder terkait, seperti Dinas Kesehatan, Dinas pemberdayaan masyarakat, Dinas perindustrian, dll agar memiliki pengetahuan dan pengalaman yang baik di dalam berproduksi. Lebih-lebih bila bergerak pada industry pengolahan, khususnya pengolahan makanan, tentu sangat berbahaya bila tidak diikuti dengan pengetahuan yang sesuai standar Kesehatan.

2. Tahap Pemasaran. Banyak ibu-ibu rumah tangga yang tiba-tiba ingin berproduksi dengan memanfaatkan sumber daya lingkungan dan memanfaatkan ketrampilan yang dimiliki dari turun temurun keluarga, lalu mempraktekkan kemampuannya tersebut untuk memproduksi kue, kacang, dan camilan lainnya, serta olahan dari berbahan dasar ikan. Seperti kerupuk, dll. Namun bila tidak diikuti dengan pengetahuan bagaimana memasarkan dan kemana sasaran pemasarannya, sehingga begitu mampu berproduksi, kemudian mandeg dan tidak berlanjut. Kalaupun mampu berproduksi dan menyasar konsumen sekitar lingkungan tempat tinggal, tetapi setelah beberapa waktu, konsumen akan sampai pada tingkat jenuh, atau datang produsen lain yang lebih baik kualitas dan harga yang bersaing, maka hal ini pasti akan menjadi masalah baru lagi dalam usaha ekonomi produktif rumahan yang dilakukan ibu-ibu tersebut.

Untuk itulah, pihak terkait dan stakeholder, khususnya Pemerintah Daerah dari mulai tingkat Desa/Kelurahan, tingkat Kecamatan sampai berikutnya harus bekerjasama dan mampu mendorong minat serta keinginan yang kuat kalangan ibu-ibu rumah tangga yang sudah memiliki kesadaran berekonomi ini ditindaklanjuti. Sehingga perlu pendampingan dan pembinaan yang terus menerus agar semangat berproduksi yang sudah tumbuh makin terpelihara dan maju seiring dengan majunya usaha ekonomi produktif yang dijalankan tersebut. Karena pada akhirnya akan memberikan dampak yang luas. Tidak saja pada ekonomi keluarga, ekonomi desa, ekonomi kecamatan dan kabupaten sehingga ekonomi negara. 
BAKTI BANUA : Jurnal Pengabdian Kepada Masyarakat

Volume 1 No. 1 Mei 2020

https://ejurnal.stimi-bjm.ac.id/index.php/BBJM/

\section{PENUTUP}

Sikap penerimaan masyarakat, khususnya ibu-ibu yang menjadi target kegiatan penyuluhan terkait peningkatan ekonomi produktif rintisan yang memang masih terkendala dalam banyak hal, patut mendapat perhatian segenap phak. Lebih-lebih stakeholder yang terkait dengan kegiatan ekonomi, kegiatan pemberdayaan, kegiatan penyuluhan, kegiatan peningkatan sumber daya manusia, dan lain-lain. Harus bisa saling bekerja sama guna menumbuhkan jiwa kewirausahaan yang sudah mulai bersemi dan bertumbuhan di desa-desa agar masyarakat mampu mengembangkan potensi diri dan sumber daya lokal yang dimiliki menjadi sumber penghasilan yang produktif bagi keluarga, masyarakat, dan negara.

Perguruan Tinggi bisa mengambil peran dalam pelatihan peningkatan sumber daya manusia melalui kemampuan manajemen usaha, manajemen produksi, manajemen pemasaran, manajemen sumber daya manusia lainnya yang bersentuhan dengan kebutuhan pelaku usaha mikro yang pada tiap-tiap desa dan daerah pasti berlainan. Keunikan sumber daya daerah/lokal harus digarap dan dikedepankan melalui pengembangan kreativitas dan inovasi masyarakat dalam berkarya dan berproduktif sehingga mampu berdaya saing dalam pasar global saat ini.

\section{UCAPAN TERIMA KASIH}

Rasa terima kasih yang amat sangat besar dari Tim Abdimas sampaikan kepada Pimpinan STIMI Banjarmasin beserta Kepala P2M serta kawan-kawan dosen, tenaga kependidikan, dan mahasiswa yang tergabung dalam kegiatan ini. Sehingga kegiatan pengabdian masyarakat ini bisa berjalan dengan baik dan lancar atas dukungan materiil dan moril yang diberikan.

\section{DAFTAR PUSTAKA}

Agustina, Titien; Candrarin, G.; Manan, A. (2017). MSMEs Challenges in Phenomena of Disruption Era. Journal of Economics and Sustainable Development, 8(21), 116-121.

Agustina, T. (2019). Improving Business Performance Through Competitive Advantage: A Study On SMES In Banjarmasin, Indonesia. Eurasia: Economic \& Business, 6(26), 39-59.

Dipta, I Wayan. 2009. Mengangkat Peran Perempuan Pengusaha Dalam Mengatasi Pengangguran. Kalarta: Kementerian Negara, Koperasi dan UKM.

Kusumawardani, Indah. 2013. Metode-Metode Penyuluhan. http://indaharitonangfakultaspertanianunpad.blogspot.com/2013/06/metode-metode-penyuluhan.html. Diakses, 16 April 2020.

Panggabean, Hasugian, M. dan. (2019). Peran Perempuan dalam Mengembangkan Usaha Mikro Kecil dan Menengah dalam rangka menuju Masyarakat Ekonomi ASEAN di Kota Tangerang Selatan. 2(2), 111-135.

Priminingtyas, D. N. (2010). Peran Perempuan Dalam Pengembangan Sektor Usaha Mikro Kecil Menengah (UMKM). 1-7.

Suryana. (2013). Kewirausahaan. Jakarta: Kencana.

Tambunan, T. (2012). Usaha Mikro Kecil dan Menengah di Indonesia: Isu-isu Penting. Jakarta: 
BAKTI BANUA : Jurnal Pengabdian Kepada Masyarakat

Volume 1 No. 1 Mei 2020

https:/ / ejurnal.stimi-bjm.ac.id/index.php/BBJM/

LP3ES.

Widayat, et. al. (2018). Pengembangan Produktivitas dan Kewirausahaan Bagi Usaha Kecil di Kelurahan Sukaramai Kecamatan Pekanbaru Kota. Jurnal Bakti Saintek: Jurnal Pengabdian Masyarakat Bidang Sains Dan Teknologi, 2(2), 51. https://doi.org/10.14421/jbs.1217 